\title{
MODEL PREDIKSI PENGARUH LIMBAH CAIR HOTEL TERHADAP KUALITAS AIR LAUT DI PESISIR TELUK KUPANG (A Prediction Model of Liquid Waste Hotel Impact on The Sea Water along The Coast of Kupang Bay)
}

\author{
Inty Megarini $^{1 *}$, Suwari ${ }^{2}$ dan Ricky Gimin ${ }^{1,3}$ \\ ${ }^{1}$ Program Studi Magister Ilmu Lingkungan, Program Pascasarjana Universitas Cendana, \\ Jl. Adisucipto, Kupang 85001. \\ ${ }^{2}$ Jurusan Kimia, Fakultas Sains dan Teknik, Universitas Cendana, Jl. Adisucipto, Kupang 85001. \\ ${ }^{3}$ Fakultas Perikanan dan Kelautan, Universitas Cendana, Jl. Adisucipto, Kupang 85001. \\ *Penulis korespondensi. Tel: 081339406105. Email: intymegariniteddy@yahoo.co.id.
}

Diterima: 9 Desember 2014

Disetujui: 29 Mei 2015

\begin{abstract}
Abstrak
Hotel-hotel di pesisir Teluk Kupang sebagian besar membuang efluen limbah cairnya ke laut. Kondisi ini akan berpengaruh terhadap kualitas air laut dan berdampak pada kelangsungan hidup biota dan mikroorganisme laut. Penelitian ini bertujuan untuk membuat prediksi pengaruh efluen limbah cair hotel yang dibuang terhadap kualitas air laut di hadapannya. Parameter yang diteliti adalah minyak dan lemak dan ortofosfat efluen limbah cair hotel. Parameter kualitas air laut yang diteliti adalah kekeruhan, minyak dan lemak dan klorofil. Metode pengambilan sampel dan pengujian menggunakan SNI dan USEPA. Analisis data menggunakan uji korelasi dan regresi. Hasil penelitian menunjukkan bahwa kekeruhan air laut pada jarak 0 meter dan 25 meter dapat diprediksi dari kadar minyak dan lemak efluen limbah cair hotel melalui model regresi $\mathrm{y}=0,0051 \mathrm{x}+4,8456$ dan $\mathrm{y}=0,0015 \mathrm{x}+4,5440$. Kadar klorofil air laut pada jarak 25 meter dan 75 meter dapat diprediksi dari kadar ortofosfat efluen limbah cair hotel melalui persamaan regresi $\mathrm{y}=0,0430 \mathrm{x}+0,0004$ dan $\mathrm{y}=0,0075 \mathrm{x}+0,0001$.
\end{abstract}

Kata kunci: kekeruhan, klorofil, kualitas air laut, minyak dan lemak, ortofosfat.

\begin{abstract}
Most of the hotels located along the coast of Kupang Bay dump their effluent liquid waste to the sea. This action will definitely affect the sea water quality and in turn, will unavoidably give deep impact on the life of both microorganism and all the living things in the sea. This research intends to make an impact prediction on the sea water quality over the dumping hotels' affluent liquid waste to the sea. The parameters which are observed are oil and fat and orthophosphate of the hotels' affluent liquid waste. While the observed parameters of the sea water quality are turbidity, oil and fat, and chlorophyll. The methods used to take and test the sample are SNI and USEPA. And to analyze the data, testing on both correlation and regression are applied. The result of the study reveals that the turbidity of the sea water within the range of 0 to 25 meters can be predicted from the level of oil and fat of the hotels' affluent liquid waste by using regression model equation $y=0.0051 x+4.8456$ and $y=0.0015 x+4.5440$. Meanwhile, the level of the sea water chlorophyll within the range of 25 to 75 meter can be predicted from the level of orthophosphate of the hotels' affluent liquid waste by using the equation of regression $y=0.0430 x+0.0004$ and $y=$ $0.0075 x+0.0001$.
\end{abstract}

Keywords: turbidity, chlorophyll, sea water quality, oil and fat, orthophosphate.

\section{PENDAHULUAN}

Salah satu sektor yang cukup berkembang di Kota Kupang adalah perhotelan. Kecenderungan investor akhir-akhir ini memilih wilayah pesisir Teluk Kupang sebagai lokasi pembangunan hotel di Kota Kupang, karena wilayah pesisir Teluk Kupang merupakan favorit bagi pengunjung sehingga diharapkan dapat memberikan keuntungan yang menjanjikan bagi investor. Keindahan pantai menjadi daya tarik tersendiri bagi hotel di wilayah pesisir. Hotel-hotel yang terkonsentrasi pada wilayah pesisir akan menyebabkan tingginya aktivitas di wilayah tersebut. Aktivitas hotel menghasilkan limbah yang tidak sedikit, baik berupa limbah organik, anorganik maupun mikrobiologis.

Sementara upaya hotel dalam pengelolaan limbahnya masih rendah. Penelitian Lensiana (2010) menunjukkan bahwa tingkat partisipasi hotel di Kecamatan Ubud, Kabupaten Gianyar, Bali dalam melakukan upaya pengolahan air limbah masih rendah. Selain itu efektivitas pengolahan air limbah yang dilakukan hotel-hotel tersebut juga 
masih rendah dan belum optimal karena teknologi yang digunakan kurang tepat dan langkah-langkah pengolahan limbahnya tidak sesuai standar. Hasil penelitian Elyazar dkk. (2007) menunjukkan bahwa jumlah limbah cair yang dihasilkan dari aktivitas hotel/restauran di Pantai Kuta, Kabupaten Badung, Bali adalah $1248-2320 \mathrm{~m}^{3} /$ hari. Penelitian ini juga menunjukkan aktivitas penduduk seperti perhotelan, restauran, permukiman, perdagangan, jasa, industri dan nelayan di Kelurahan Kuta memberikan dampak bagi lingkungan khususnya air laut. Data lain berdasarkan pengujian kualitas air laut di Kota Kupang (Anonim, 2013), menunjukkan bahwa di beberapa titik di wilayah pesisir telah melampaui Baku Mutu Air Laut Peruntukkan Biota Laut.

Limbah cair yang dihasilkan memerlukan pengolahan terlebih dahulu sebelum dibuang ke badan air agar tidak menimbulkan pencemaran pada badan air. Sebagian besar hotel di pesisir Kota Kupang membuang limbah cairnya ke perairan terdekatnya. Limbah cair yang dibuang tersebut ada yang telah melalui pengolahan, namun ada pula yang tidak melalui pengolahan terlebih dahulu. Unit pengolahan limbah cair yang dimiliki beberapa hotel di pesisir Kota Kupang ada yang belum memenuhi standar pengolahan limbah cair hotel. Hal ini dapat menyebabkan kualitas efluen yang dihasilkan juga tidak memenuhi baku mutu limbah cair bagi kegiatan perhotelan. Akibatnya efluen yang dibuang ke perairan dapat berpengaruh terhadap status mutu air laut yang berhadapan langsung dengan hotel-hotel tersebut.

Penelitian ini mengkaji pengaruh parameter limbah cair hotel yaitu minyak dan lemak serta ortofosfat terhadap kualitas air laut yang berhadapan dengan hotel di Teluk Kupang. Tujuan penelitian adalah membuat model prediksi pengaruh parameter limbah cair hotel yaitu minyak dan lemak serta ortofosfat terhadap kualitas air laut yang berhadapan dengan hotel di Teluk Kupang. Kebaruan penelitian ini adalah peneliti mengulang beberapa metode dari penelitian-penelitian terdahulu pada lokasi yang berbeda (baru) yaitu di perairan teluk Kupang, yaitu penelitian Bachtiar dkk., (2005) mengenai kajian temporal akibat pengaruh limbah domestik dan pola penyebarannya di perairan pantai Kartini Jepara, Suhartono (2009) mengenai identifikasi kualitas perairan pantai akibat limbah domestik pada monsun timur dengan metode indeks pencemaran, Winarno (2013) mengenai tingkat pencemaran limbah cair domestik di perairan pesisir Kecamatan Tanjungpinang Barat Kota Tanjungpinang Provinsi Kepulauan Riau, Darmawan dan Masduqi (2014) mengenai indeks pencemaran air laut pantai utara Tuban dengan parameter TSS dan kimia non-logam, Lensiana
(2010) mengenai partisipasi hotel dalam pengelolaan lingkungan di Kecamatan Ubud Kabupaten Gianyar (studi kasus terhadap sistem pengelolaan limbah hotel) dan Elyazar (2007) mengenai dampak aktivitas masyarakat terhadap tingkat pencemaran air laut di pantai kuta Kabupaten Badung serta upaya pelestarian lingkungan. Kebaruan yang lain adalah peneliti mengamati fenomena pertumbuhan hotel di pesisir teluk Kupang yang sangat pesat akhir-akhir ini sehingga menimbulkan ide baru dari peneliti untuk mengetahui pengaruh efluen limbah cair hotel di pesisir teluk Kupang terhadap perairan teluk Kupang.

\section{METODE PENELITIAN}

\section{Waktu dan Lokasi}

Penelitian ini dilakukan selama 5 (lima) bulan sejak bulan Juni - Nopember 2014. Lokasi penelitian di 3 (tiga) hotel di pesisir Teluk Kupang yang berhadapan langsung dengan perairan Teluk Kupang, yaitu Hotel A, B dan C. Hotel-hotel ini berbatasan langsung dengan garis pantai Kota Kupang tanpa dibatasi oleh daratan. Definisi garis pantai (coastline) menurut Peraturan Menteri Dalam Negeri Nomor 76 Tahun 2012 tentang Pedoman Penegasan Batas Daerah. Lokasi penelitian ditampilkan pada Gambar 1.

\section{Bahan dan Alat}

Bahan-bahan utama yang digunakan dalam penelitian ini berupa bahan kimia campuran pelarut organik (n-heksan dan Methyl tert buthyl ether (MTBE)), $\mathrm{Na}_{2} \mathrm{SO}_{4}$ anhidrat, PhosVer ${ }^{\circledR} 3$ phosphate reagent powder pillow, aceton $90 \%$ dan air bebas mineral.

Peralatan utama yang digunakan adalah peralatan pengambilan sampel berupa Van Dorn dan peralatan pengujian laboratorium yaitu neraca analitik, penangas air, furnace, desikator, turbidimeter, spektrofotometer, dan centrifuge.

\section{Prosedur Kerja}

Pengambilan sampel efluen limbah cair hotel

Pengambilan sampel efluen limbah cair hotel dilakukan dengan menggunakan alat pengambil contoh yang sesuai dengan saluran pembuangan. Pertama-tama dilakukan pembilasan alat dengan efluen limbah cair hotel sebanyak 3 (tiga) kali. Kemudian sampel diambil dan dihomogenkan. Sampel kemudian dimasukkan ke dalam wadah sesuai peruntukan analisis dan diawetkan. Pengujian lapangan dilakukan terhadap parameter suhu dan $\mathrm{pH}$ karena parameter ini dapat berubah dengan cepat dan tidak dapat diawetkan (SNI 6989.59:2008). 


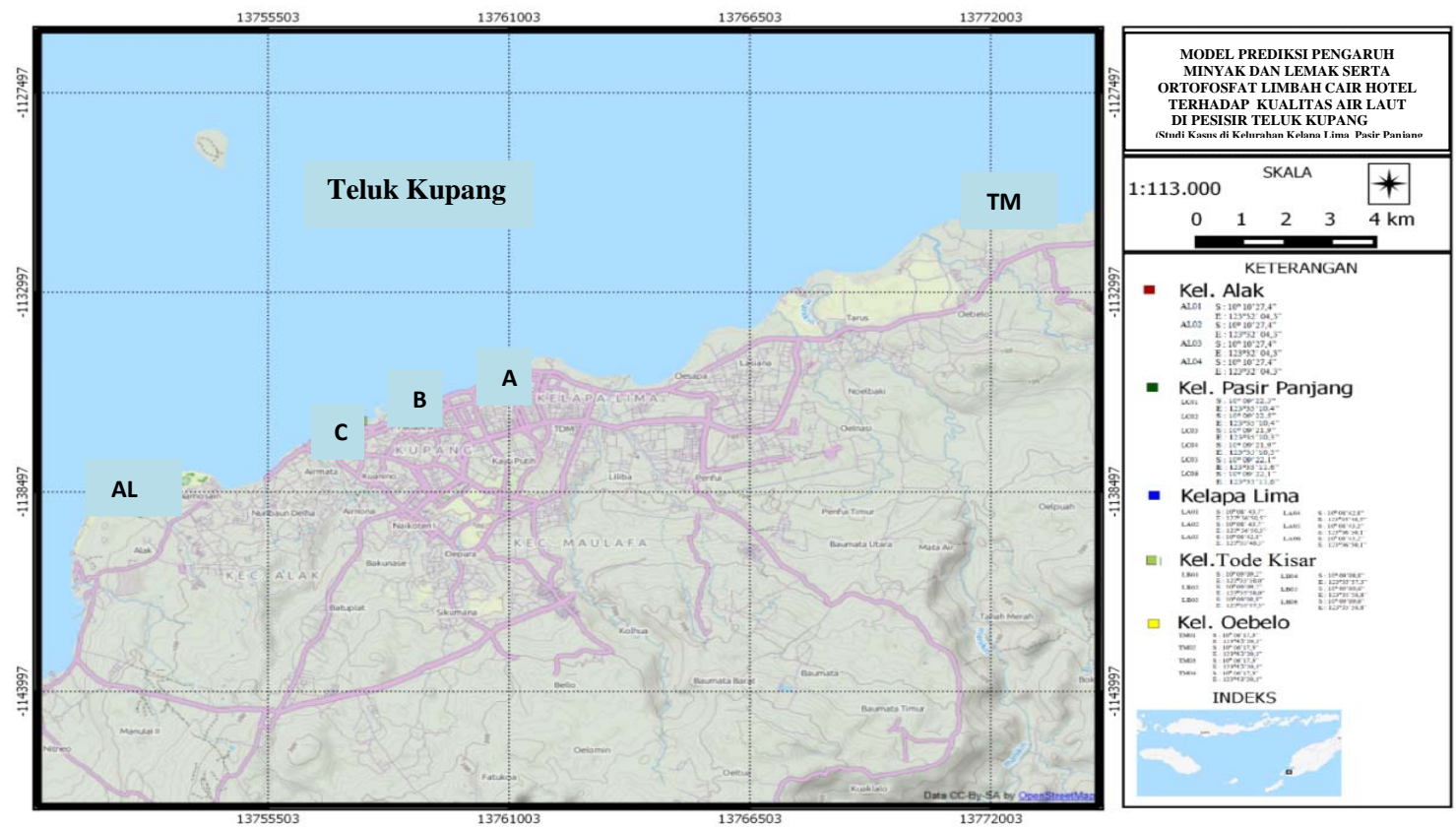

Gambar 1. Lokasi penelitian Hotel A, Hotel B, Hotel C, TM (alami 1) dan AL (alami 2).

\section{Pengambilan sampel air laut}

Sebelum dilakukan pengambilan sampel air laut, terlebih dahulu dilakukan persiapan alat sampling dan wadah sampel. Kemudian alat pengambil contoh dibilas (sebagai blangko alat). Wadah yang akan digunakan juga dibilas dengan dengan aquades (sebagai blangko wadah). Alat pengambilan contoh dibilas dengan air yang akan diambil. Sampel kemudian diambil dan dihomogenkan. Sampel dimasukkan ke dalam wadah sesuai peruntukan analisis dan diawetkan. Pengujian lapangan dilakukan terhadap parameter suhu dan $\mathrm{pH}$ karena parameter ini dapat berubah dengan cepat dan tidak dapat diawetkan (SNI 6989.57:2008).

\section{Pengujian laboratorium}

Untuk limbah cair hotel diukur kadar minyak dan lemak dan kadar ortofosfat. Pengujian dilakukan dengan prosedur seperti diterangkan berikut. Prosedur analisis minyak dan lemak diawali dengan ekstraksi contoh uji air menggunakan pelarut organik dalam corong pisah. Untuk menghilangkan air yang masih tersisa digunakan $\mathrm{Na}_{2} \mathrm{SO}_{4}$ anhidrat. Ekstrak minyak dan lemak dipisahkan dari pelarut organik secara destilasi. Residu yang tertinggal pada labu destilasi ditimbang sebagai minyak dan lemak (SNI 066989.10-2004).

Prosedur penentuan kadar ortofosfat dilakukan dengan pengambilan sampel di dalam Cell yang kemudian ditambahkan 1 PhosVer ${ }^{\circledR} 3$ Phosphate Reagent Powder Pillow. Kemudian Cell yang berisi sampel ditempatkan di atas dudukan Cell Spektrofotometer Hach DR 2800. Kandungan ortophospat dalam sampel dibaca oleh Spektrofotometer Hach DR 2800 dalam satuan $\mathrm{mg} / \mathrm{L} \mathrm{PO}_{4}{ }^{3-}$ (USEPA and Standard Method 4500-P$\mathrm{E}$ for wastewater).

Penentuan kualitas air laut dilakukan dengan mengukur kadar kekeruhan, minyak dan lemak dan kadar klorofil. Prosedur analisis kekeruhan diawali dengan mengocok contoh uji air laut. Kemudian contoh uji dimasukkan pada tabung dalam nefelometer. Nilai pembacaan stabil pada nefelometer merupakan kadar kekeruhan air laut (SNI 06-6989.25-2005).

Untuk penentuan kadar minyak dan lemak air laut dilakukan dengan ekstraksi contoh uji air menggunakan pelarut organik dalam corong pisah. Kemudian untuk menghilangkan air yang masih tersisa digunakan $\mathrm{Na}_{2} \mathrm{SO}_{4}$ anhidrat. Ekstrak minyak dan lemak dipisahkan dari pelarut organik secara destilasi. Residu yang tertinggal pada labu destilasi ditimbang sebagai minyak dan lemak. (SNI 066989.10-2004).

Prosedur penentuan kadar klorofil air laut diawali dengan menyaring sampel sebanyak 5-10 L menggunakan kertas saring $0,45 \mu \mathrm{m}$. Sampel yang telah disaring kemudian diekstrak menggunakan aceton $90 \%$. Selanjutnya sampel diaduk dengan menggunakan centrifuge sebanyak $4000 \mathrm{rpm}$ selama $\pm 30-45$ menit. Setelah dicentrifuge, sampel kemudian diukur absorbansinya pada spektrofotometer dengan panjang gelombang 750 , 665, 645 dan $630 \mathrm{~nm}$. Hasil pengukuran dimasukkan ke rumus untuk perhitungan klorofil-a. (Richards dan Tompson, 1952 dalam Riyono, 2006). 


\section{Metode analisis}

Digunakan metode uji korelasi untuk mengetahui kekuatan dan arah hubungan antara parameter efluen limbah cair hotel dengan parameter kualitas air laut. Kemudian dilakukan analisis regresi linier untuk menentukan model prediksi.

\section{HASIL DAN PEMBAHASAN}

\section{Kualitas Air Laut yang Berhadapan dengan Hotel}

Pada penelitian ini dilakukan analisis laboratorium terhadap parameter effluen limbah cair hotel, yaitu minyak dan lemak serta ortophospat. Waktu pengambilan sampel disesuaikan dengan perkiraan aktivitas sibuk di hotel dan waktu pasang dan surut air laut, yaitu pada pukul 12.00-13.00 dan 16.00-17.00 Wita. Jenis parameter air laut yang dianalisis adalah kekeruhan, minyak dan lemak, dan klorofil. Pengambilan sampel dilakukan dengan variasi jarak titik sampel dari hotel yaitu pada jarak 0 meter, 25 meter dan 75 meter. Pengambilan sampel pada jarak 0 dan 25 meter dilakukan pada waktu air laut pasang yaitu pada Pukul 12.00-13.00 Wita. Pengambilan sampel untuk jarak 75 meter dilakukan pada saat air laut surut yaitu pada pukul 16.00-17.00 Wita. Hasil analisis kualitas efluen dan air laut ditampilkan pada Tabel 1 pada lampiran. Kandungan kekeruhan air laut pada variasi jarak 0 , 25 dan 75 meter dari hotel A, B, C dan lokasi alami (pristine) ditampilkan pada Gambar 2.

Gambar 2 menunjukkan kekeruhan air laut pada lokasi alami (pristine) (titik TM01, TM02, TM03, TM04, AL01, AL02, AL03 dan AL04) cenderung lebih stabil di banding kualitas air laut yang berhadapan dengan hotel yang lebih fluktuatif (titik LA01, LA02, LA03, LA04, LA05, LA06,
LB01, LB02, LB03, LB04, LB05, LB06, LC01, LC02, LC03, LC04, LC05, dan LC06). Kondisi ini menunjukkan pengaruh efluen limbah cair hotel terhadap kualitas air laut di hadapannya. Kekeruhan disebabkan oleh keberadaan bahan organik dan anorganik yang tersuspensi dan terlarut (misalnya lumpur dan pasir halus), maupun bahan anorganik dan organik yang berupa plankton dan mikroorganisme lain (Effendi, 2003). Kekeruhan dapat mengakibatkan terganggunya sistem osmoregulasi, misalnya pernafasan dan daya lihat organisme akuatik, serta dapat menghambat penetrasi cahaya ke dalam air (Effendi, 2003).

Pada titik-titik sampel air laut yang berhadapan dengan hotel terdapat 10 titik yang tidak memenuhi Baku Mutu. Ke-10 titik tersebut berada pada perairan yang berhadapan dengan hotel. Pada titik sampel LA05 dan LA06 yang berada pada jarak $75 \mathrm{~m}$ dari hotel dan diambil pada saat air laut surut memiliki kekeruhan di atas baku mutu, hal ini dapat dimungkinkan disebabkan oleh efluen limbah cair hotel yang memiliki kandungan TSS cukup tinggi yaitu di atas baku mutu. Tidak adanya faktor pengenceran karena air laut sedang surut memungkinkan kekeruhan disebabkan oleh TSS dari efluen limbah cair hotel sebagaimana diketahui bahwa padatan tersuspensi berkorelasi positif dengan kekeruhan (Effendi, 2003). Pada titik LB01, LB 02, LB03, LB04, LC01, LC02, LC03, dan LC04 yang berada pada jarak 0-25 m dari hotel $\mathrm{B}$ dan $\mathrm{C}$ juga memiliki kekeruhan yang melampaui baku mutu. Hal ini dimungkinkan kekeruhan terjadi akibat bahan-bahan tersuspensi yang berukuran lebih besar misalnya lapisan permukaan dasar perairan atau pasir laut yang terhempas karena gelombang. Mengingat sampel diambil pada saat air pasang dan gelombang cukup besar menghempas talud penahan gelombang.

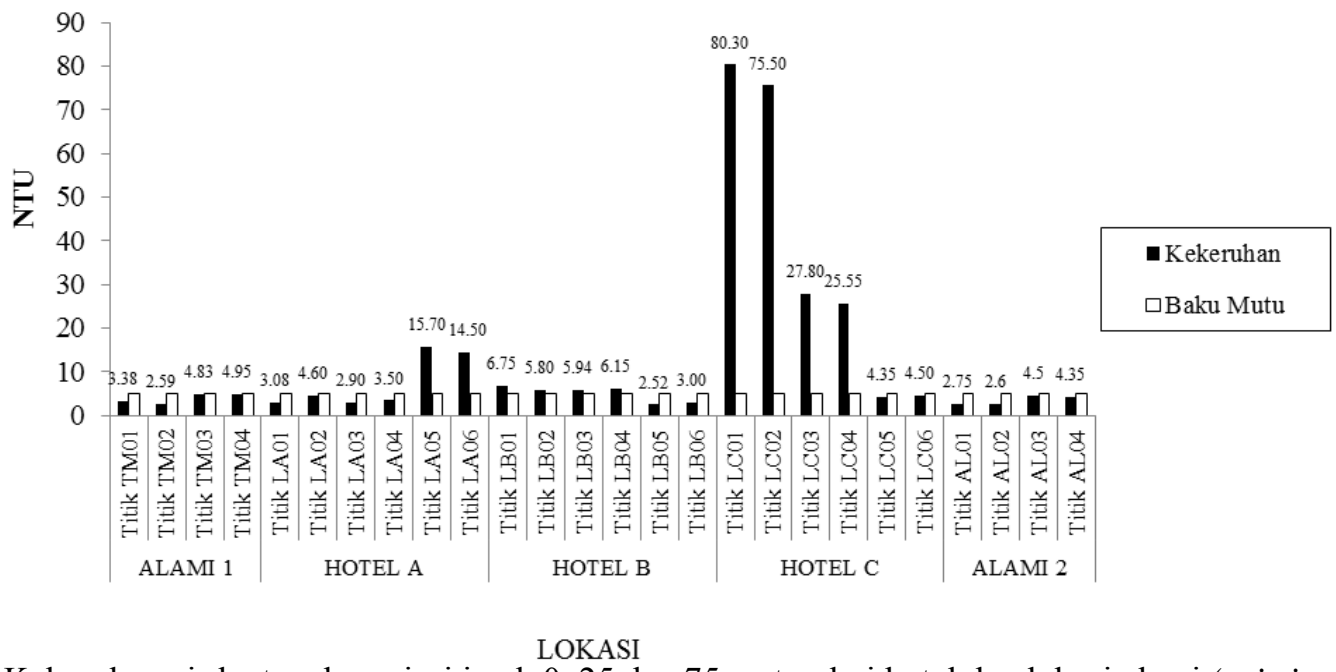

Gambar 2. Kekeruhan air laut pada variasi jarak 0, 25 dan 75 meter dari hotel dan lokasi alami (pristine). 


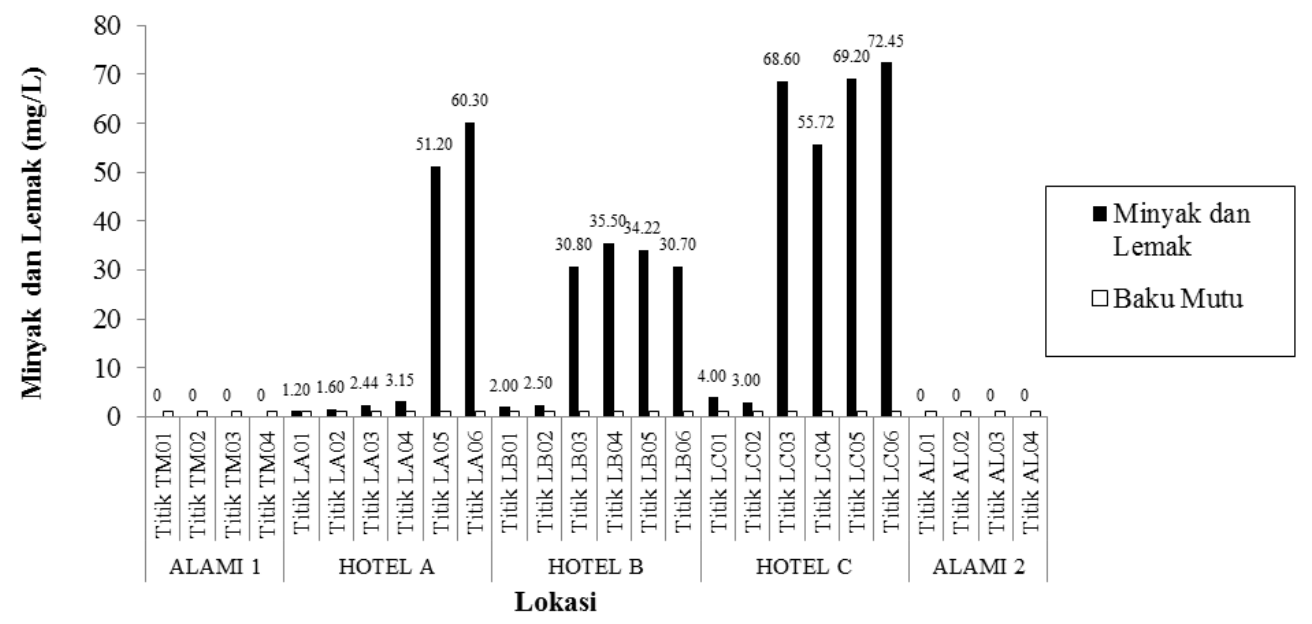

Gambar 3. Kandungan minyak dan lemak air laut pada variasi jarak 0, 25 dan 75 meter dari hotel dan lokasi alami (pristine).

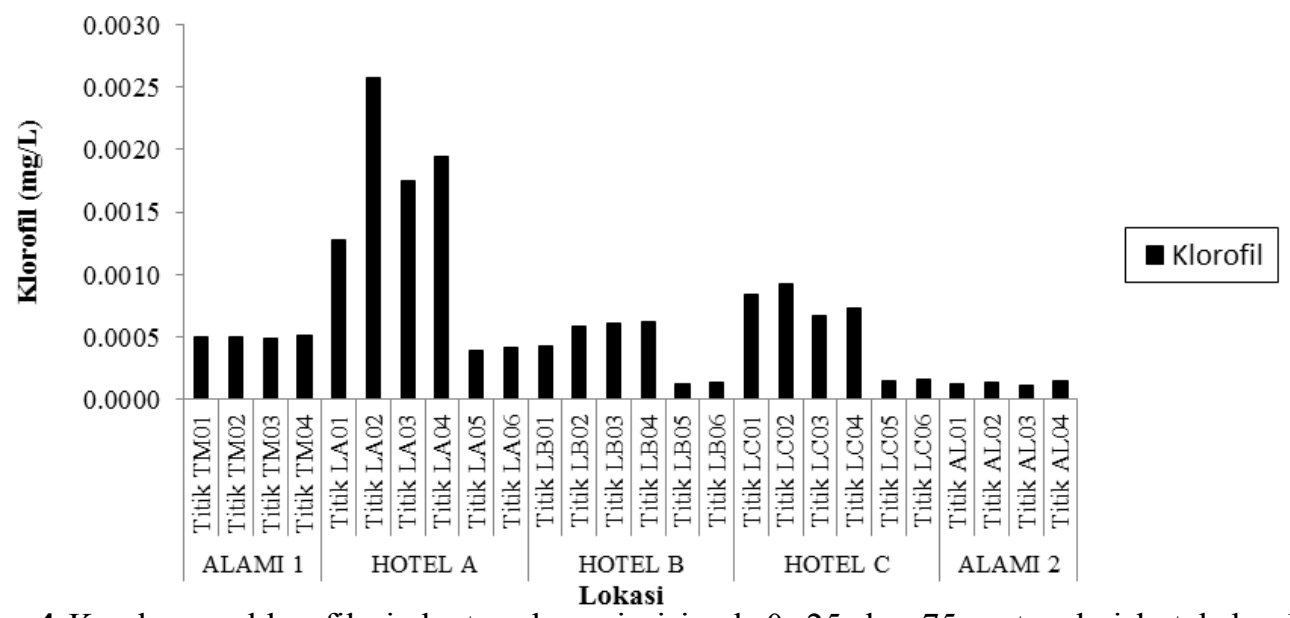

Gambar 4 Kandungan klorofil air laut pada variasi jarak 0, 25 dan 75 meter dari hotel dan lokasi alami (pristine).

Kandungan minyak dan lemak air laut pada variasi jarak 0, 25 dan 75 meter dari hotel $\mathrm{A}, \mathrm{B}, \mathrm{C}$ dan lokasi alami (prinstine) ditampilkan pada Gambar 3. Gambar 3. menunjukkan kandungan minyak dan lemak air laut pada lokasi alami (prinstine) (titik TM01, TM02, TM03, TM04, AL01, AL02, AL03 dan AL04) cenderung lebih stabil di banding kualitas air laut yang berhadapan dengan hotel yang lebih fluktuatif (titik LA01, LA02, LA03, LA04, LA05, LA06, LB01, LB02, LB03, LB04, LB05, LB06, LC01, LC02, LC03, LC04, LC05, dan LC06). Pada lokasi alami, kandungan minyak dan lemak air laut adalah 0 $\mathrm{mg} / \mathrm{L}$. Perbedaan ini menunjukkan terdapat pengaruh buangan efluen limbah cair hotel yang mengandung minyak lemak pada titik-titik sampel yang berhadapan langsung dengan hotel. Dari ke-26 titik sampel air laut baik pada kondisi alami maupun pada lokasi yang berhadapan dengan hotel, terdapat 18 titik yang tidak memenuhi Baku Mutu. Ke-18 titik tersebut seluruhnya berada di lokasi perairan yang berhadapan langsung dengan hotel.
Ke-18 titik yang memiliki nilai kandungan minyak dan lemak yang melebihi baku mutu berada pada kisaran nilai 1,29-72,45 mg/L. Kandungan minyak dan lemak air laut yang berhadapan dengan hotel yang melebihi baku mutu (1 mg/L) dimungkinkan berasal dari efluen limbah cair hotel yang juga memiliki kandungan minyak dan lemak yang cukup tinggi pada beberapa titik sampel yang dapat dilihat pada Lampiran 1.

Aktivitas hotel yang berpotensi menghasilkan efluen limbah cair berupa minyak dan lemak adalah dapur dan restaurant. Menurut Rump dan Krist (1992) dalam Effendi (2003), kandungan minyak dan lemak dari efluen limbah cair hotel yang $\geq 20$ $\mathrm{mg} / \mathrm{L}$ memiliki tingkat pencemaran sedang-berat. Pada titik-titik yang berhadapan dengan Hotel A dan $\mathrm{C}$, kandungan minyak dan lemak cenderung meningkat pada saat air surut. Hal ini sesuai dengan hasil penelitian Nedi (2010), mengenai karakteristik lingkungan perairan selat Rupat pada saat arus surut, polutan minyak yang berasal dari aktivitas daratan akan ikut bergerak mengikuti gerakan arus 
dan menyebar ke perairan sekitarnya. Kecepatan arus sangat mempengaruhi gerakan minyak. Fakta ini mendukung hasil sehingga pada jarak $75 \mathrm{~m}$ dari hotel (air surut) kandungan minyak dan lemak cenderung lebih tinggi dibanding pada jarak 0 dan 25 meter (air pasang).

Kandungan klorofil air laut pada variasi jarak 0, 25 dan 75 meter dari hotel A, B, C dan lokasi alami (prinstine) ditampilkan pada Gambar 4. Gambar 4 menunjukkan kandungan klorofil air laut pada lokasi alami dan lokasi yang berhadapan dengan hotel. Pada lokasi alami (prinstine), kandungan klorofil cenderung stabil. Untuk lokasi yang berhadapan dengan hotel, kandungannya berfluktuatif akibat pengaruh efluen limbah cair hotel. Menurut Nuriya dkk (2010), mengenai pengukuran konsentrasi klorofil-a dengan pengolahan citra Landsat ETM-7 dan uji laboratorium di perairan selat Madura bagian barat menyatakan bahwa umumnya sebaran konsentrasi klorofil tinggi di perairan pantai sebagai akibat dari tingginya suplai nutrien yang berasal dari daratan. Namun sebaliknya cenderung rendah di daerah lepas pantai karena pada daerah lepas pantai ini tidak mendapat suplai nutrien dari daratan.

Model Prediksi Pengaruh Efluen Limbah Cair Hotel Terhadap Kualitas Air Laut yang Berhadapan Langsung dengan Hotel

Berdasarkan data uji korelasi antara parameter efluen limbah cair hotel dengan parameter kualitas air laut pada sub bab sebelumnya, diketahui terdapat pola hubungan korelasi yang sangat kuat antar beberapa parameter efluen limbah cair dengan beberapa parameter air laut yang arahnya konsisten pada jarak 0 dan jarak 25 meter maupun pada ketiga jarak, yaitu jarak 0,25 dan 75 meter. Nilai koefisien korelasi sangat kuat dan konsisten arahnya antara parameter efluen limbah cair hotel terhadap parameter air laut ditampilkan pada Tabel 1.

Berdasarkan data pada Tabel 1 akan dibuat suatu model prediksi antara konsentrasi parameter kualitas efluen limbah cair hotel terhadap konsentrasi parameter kualitas air laut. Model prediksi antara parameter minyak dan lemak efluen limbah cair hotel terhadap parameter kekeruhan air laut ditampilkan pada Gambar 5.

Pada Gambar 5 (a) diketahui bahwa nilai kekeruhan air laut pada jarak 0 meter dari hotel dapat diprediksi dengan persamaan regresi $\mathrm{y}=$ $0,005 \mathrm{x}+4,845$. $\mathrm{Y}$ adalah nilai kekeruhan air laut pada jarak 0 meter dan $\mathrm{x}$ adalah kandungan minyak lemak efluen limbah cair hotel. Nilai 4,845 merupakan bilangan konstan yang menunjukkan intersep, yaitu perpotongan sumbu y pada saat $\mathrm{x}=$ 0 . Pada jarak 0 meter kenaikan 1 satuan unit minyak dan lemak efluen limbah cair hotel diprediksi akan diikuti dengan kenaikan sebesar 4,85 satuan unit kekeruhan air laut. Pengaruh nilai minyak dan lemak efluen limbah cair hotel terhadap nilai kekeruhan air laut adalah sebesar 99,8\%.

Tabel 1. Nilai koefisien korelasi sangat kuat dan konsisten arahnya antara beberapa parameter efluen limbah cair hotel terhadap parameter air laut.

\begin{tabular}{ccccc}
\hline Hubungan & & \multicolumn{3}{c}{ Koefisien korelasi } \\
\hline Parameter efluen limbah cair hotel & Parameter air laut & $0(\mathrm{~m})$ & $25(\mathrm{~m})$ & $75(\mathrm{~m})$ \\
\hline Minyak dan lemak & Kekeruhan & 0,999 & 0,994 & - \\
Ortophospat & Klorofil & - & 0,985 & 0,997 \\
\hline
\end{tabular}

Sumber : Hasil analisis dan perhitungan.

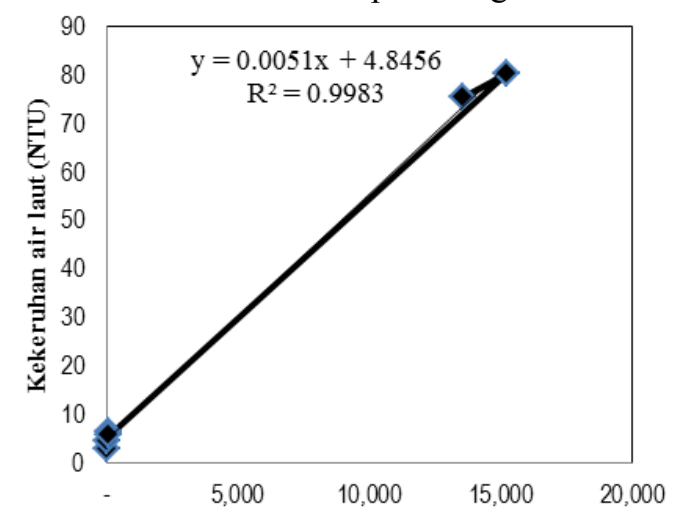

Minyak dan lemak eflluen limbah cair hotel (mg/L)

(a)

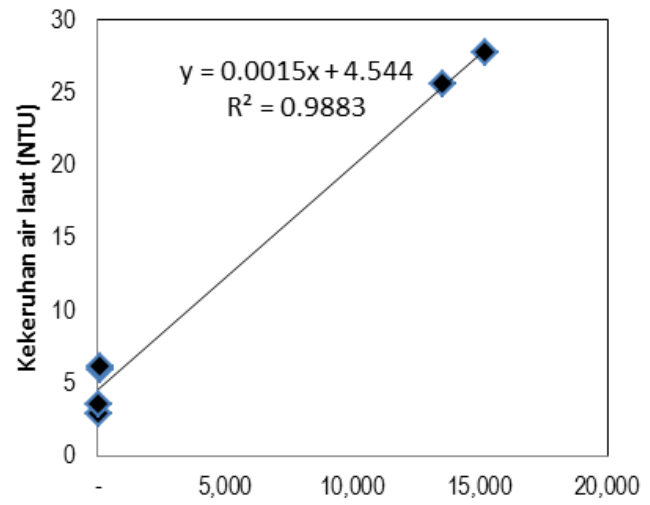

Minyak dan lemak efluen limbah cair hotel(mg/L)

(b)

Gambar 5. Model prediksi minyak dan lemak efluen limbah cair hotel terhadap kekeruhan pada jarak (a) 0 meter dan (b) 25 meter dari hotel. 


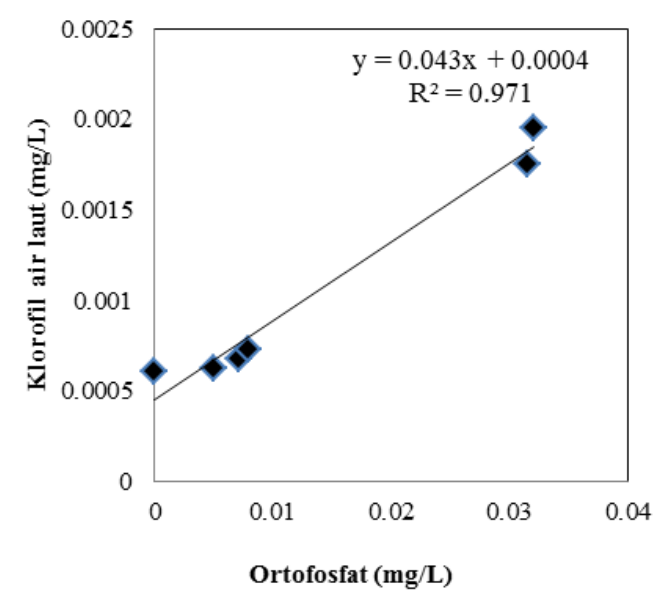

(a)

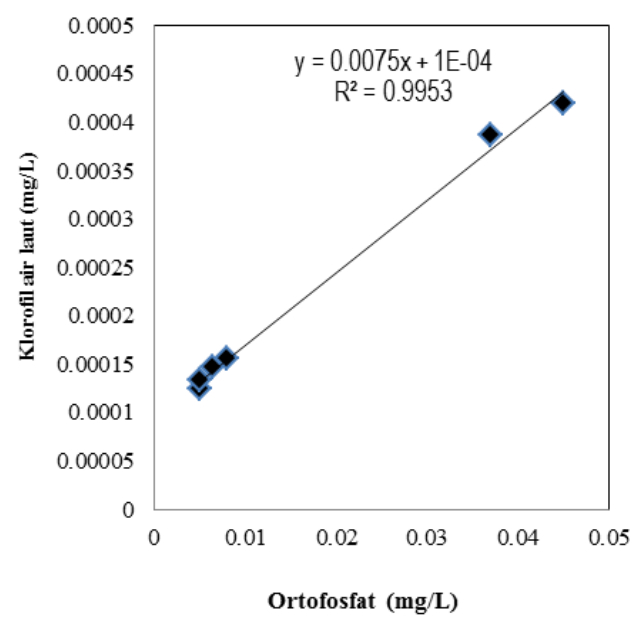

(b)

Gambar 6. Model prediksi ortofosfat limbah cair hotel terhadap klorofil air laut pada jarak (a) 25 meter dan (b) 75 meter dari hotel.

Model prediksi minyak dan lemak efluen limbah cair hotel terhadap kekeruhan air laut pada jarak 25 meter dari hotel ditampilkan pada Gambar 5 (b). Prediksi nilai kekeruhan air laut pada jarak 25 dapat diketahui menggunakan persamaan regresi y $=0,001 \mathrm{x}+4,554$. Nilai kekeruhan air laut (y) pada jarak 25 meter dan $\mathrm{x}$ adalah kandungan minyak lemak efluen limbah cair hotel. Bilangan konstan sebesar 4,544 menunjukkan intersep yang merupakan perpotongan sumbu y pada saat $\mathrm{x}=0$. Pada jarak 25 meter, setiap kenaikan 1 satuan unit minyak dan lemak efluen limbah cair hotel diprediksi akan diikuti dengan kenaikan sebesar 4,545 satuan unit kekeruhan air laut. Pengaruh nilai minyak dan lemak efluen limbah cair hotel terhadap nilai kekeruhan air laut adalah sebesar 98,8 \%.

Untuk model prediksi antara ortofosfat limbah cair hotel terhadap parameter klorofil air laut ditampilkan pada Gambar 6. Pada Gambar 6 (a) ditunjukkan model prediksi ortofosfat efluen limbah cair hotel terhadap klorofil air laut pada jarak 25 meter. Persamaan regresinya adalah $\mathrm{y}=$ $0,043 x+0,0004$. Dimana y adalah nilai klorofil air laut pada jarak 25 meter dan $\mathrm{x}$ adalah kandungan ortofosfat efluen limbah cair hotel. Nilai 0,0004 merupakan bilangan konstan yang menunjukkan intersep, yaitu perpotongan sumbu y pada saat $\mathrm{x}=$ 0 . Pada jarak 25 meter kenaikan 1 satuan unit ortophospat efluen limbah cair hotel diprediksi akan diikuti dengan kenaikan sebesar 0,0434 satuan unit klorofil air laut. Pengaruh nilai ortophospat efluen limbah cair hotel terhadap nilai klorofil air laut adalah sebesar 97,1\%.

Prediksi nilai ortofosfat efluen limbah cair hotel terhadap klorofil air laut pada jarak 75 meter ditunjukkan pada Gambar 6 (b), dengan persamaan regresinya adalah $\mathrm{y}=0,007 \mathrm{x}+0,0001$. $\mathrm{Y}$ adalah nilai klorofil air laut pada jarak 75 meter dan $\mathrm{x}$ adalah kandungan ortofosfat efluen limbah cair hotel. Perpotongan sumbu y pada saat $\mathrm{x}=0$ (intersep) sebesar 0,0001 yang merupakan bilangan konstan. Pada jarak 75 meter kenaikan 1 satuan unit ortophospat efluen limbah cair hotel diprediksi akan diikuti dengan kenaikan sebesar 0,0071 satuan unit klorofil air laut. Tingkat pengaruh nilai ortofosfatt efluen limbah cair hotel terhadap nilai klorofil air laut adalah sebesar 99,5\%.

Berdasarkan besarnya nilai $\mathrm{R}^{2}$, diketahui bahwa pada jarak 75 meter kandungan ortofosfat efluen limbah cair hotel lebih besar pengaruhnya terhadap klorofil air laut dibanding pada jarak 25 meter, sedangkan pada jarak 25 meter kandungan ortofosfat efluen limbah cair hotel lebih besar pengaruhnya terhadap klorofil air laut dibanding pada jarak 0 meter.

\section{KESIMPULAN}

Hasil penelitian menunjukkan kadar kekeruhan dan minyak dan lemak pada beberapa titik sampel air laut di perairan teluk Kupang yang berhadapan dengan hotel telah melampaui baku mutu. Berdasarkan model prediksi diketahui limbah cair hotel berpengaruh terhadap kualitas air laut di pesisir teluk Kupang. Pengaruh terbesar efluen limbah cair hotel terhadap kualitas air laut ditunjukkan oleh model prediksi nilai minyak dan lemak efluen limbah cair hotel terhadap nilai kekeruhan air laut pada jarak 0 meter yaitu sebesar $99,8 \%$. Sementara model prediksi kadar ortophospat efluen limbah cair hotel terhadap kadar klorofil air laut pada jarak 75 meter dari hotel menunjukkan nilai sebesar 99, $5 \%$. Parameter minyak dan lemak efluen limbah cair hotel 
mempunyai pengaruh yang cukup kuat terhadap kadar kekeruhan air laut pada jarak 25 meter dengan nilai pengaruhnya sebesar $98,8 \%$. Untuk kadar ortophospat mempunyai pengaruh terhadap klorofil air laut pada jarak 25 meter sebesar 97, 7 $\%$.

\section{DAFTAR PUSTAKA}

Anonim, 2012. Peraturan Menteri Dalam Negeri Nomor 76 Tahun 2012 tentang Pedoman Penegasan Batas Daerah. Kementerian Dalam Negeri, Jakarta.

Anonim, 2013. Pengujian Kualitas Air Laut di 7 (Tujuh) Kabupaten/Kota se-Provinsi NTT. Badan Lingkungan Hidup Daerah Provinsi NTT, Kupang.

Bachtiar, T., Khasanah, U., Radjasa, Ocky K., Suhartono, E., dan Hadiyarto, A., 2005. Kajian Temporal Indeks Pencemaran Akibat Pengaruh Limbah Domestik dan Pola Penyebarannya di Perairan Pantai Kartini Jepara. Jurnal Ilmu Kelautan, 10(4):213-220.

Darmawan, H., dan Masduqi, A., 2014. Indeks Pencemaran Air Laut Pantai Utara Tuban Dengan Parameter TSS dan Kimia Non Logam. Jurnal Teknik POMITS, 3(1):D16D20.

Effendi, H., 2003. Telaah Kualitas Air Bagi Pengelolaan Sumber Daya dan Lingkungan Perairan. Edisi Kelima. Penerbit Kanisius, Yogyakarta.
Elyazar, N., Mahendra., M.S., dan Wardi., I.N., 2007. Dampak Aktivitas Masyarakat Terhadap Tingkat Pencemaran Air Laut di Pantai Kuta Kabupaten Bandung Serta Upaya Pelestarian Lingkungan. Ecotrophic 2(1):1-18.

Lensiana, 2010. Partisipasi Hotel Dalam Pengelolaan Lingkungan di Kecamatan Ubud Kabupaten Gianyar. Program Pascasarjana, Universitas Udayana, Denpasar.

Nedi, S., Pramudya, B., Riani, E., dan Manuwoto, 2010. Karakteristik Lingkungan Perairan Selat Rupat. Jurnal of Environmental Science, $1(4): 25-35$.

Nuriya, H., Hidayah, Z., dan Nugraha, W.A., 2010, Pengukuran Konsentrasi Klorofil-a Dengan Pengolahan Citra Landsat ETM-7 dan Uji Laboratorium di Perairan Selat Madura Bagian Barat. Jurnal Kelautan, 3(1):60-65.

Riyono, S.H., 2006. Beberapa Metode Pengukuran Klorofil Fitoplankton di Laut. Jurnal Oseana, 31(3):33-44.

Suhartono, 2009. Identifikasi Kualitas Perairan Pantai Akibat Limbah Domestik Pada Monsun Timur Dengan Metode Indeks Pencemaran (Studi Kasus di Jakarta, Semarang dan Jepara). Wahana Teknik Sipil, 14(1):51-62.

Winarno, 2013, Tingkat Pencemaran Limbah Cair Domestik di Perairan Pesisir Kecamatan Tanjungpinang Barat Kota Tanjungpinang Provinsi Kepulauan Riau, Skripsi, Fakultas Ilmu Kelautan Dan Perikanan, Universitas Maritim Raja Ali Haji, Tanjungpinang. 
Lampiran 1. Kualitas efluen limbah cair hotel dan air laut.

\begin{tabular}{|c|c|c|c|c|c|c|}
\hline \multirow{2}{*}{ Lokasi } & \multirow[t]{2}{*}{ Titik sampel } & \multicolumn{4}{|c|}{ Parameter } & \multirow[t]{2}{*}{ Keterangan } \\
\hline & & $\begin{array}{c}\text { Minyak dan } \\
\text { lemak }(\mathrm{mg} / \mathrm{L})\end{array}$ & $\begin{array}{l}\text { Ortofosfat } \\
\text { (mg/L) }\end{array}$ & $\begin{array}{l}\text { Kekeruhan } \\
\text { (NTU) }\end{array}$ & $\begin{array}{c}\text { Klorofil } \\
(\mathrm{mg} / \mathrm{L})\end{array}$ & \\
\hline \multirow{15}{*}{$\begin{array}{c}\text { Hotel A } \\
\text { (Kelas Bintang 3) }\end{array}$} & Efluen 1: & & & & & Pukul 12.00-13.00 \\
\hline & & 13,60 & 0,031 & - & - & \\
\hline & & 15,00 & 0,032 & - & - & \\
\hline & Jarak $0 \mathrm{~m}$ : & & & & & Pasang \\
\hline & LA01 & 1,20 & - & 3,08 & $1,2 \times 10^{-3}$ & \\
\hline & LA02 & 1,60 & - & 4,60 & $2,5 \times 10^{-3}$ & \\
\hline & Jarak $25 \mathrm{~m}$ : & & & & & Pasang \\
\hline & LA03 & 2,44 & - & 2,90 & $1,7 \times 10^{-3}$ & \\
\hline & LA04 & 3,15 & - & 3,50 & $1,9 \times 10^{-3}$ & \\
\hline & Efluen 2 : & & & & & Pukul 16.00-17.00 \\
\hline & & 8,60 & 0,037 & - & - & \\
\hline & & 10,50 & 0,045 & - & - & \\
\hline & Jarak $75 \mathrm{~m}$ : & & & & & Surut \\
\hline & LA05 & 51,20 & - & 15,70 & $3,8 \times 10^{-4}$ & \\
\hline & LA06 & 60,30 & - & 14,50 & $4,1 \times 10^{-4}$ & \\
\hline \multirow{15}{*}{$\begin{array}{c}\text { Hotel B } \\
\text { (Kelas Bintang 3) }\end{array}$} & Efluen 1: & & & & & Pukul 12.00-13.00 \\
\hline & & 85,20 & 0,000 & - & - & \\
\hline & & 91,50 & 0,005 & - & - & \\
\hline & Jarak $0 \mathrm{~m}$ : & & & & & Pasang \\
\hline & LB01 & 2,00 & - & 6,75 & $4,2 \times 10^{-4}$ & \\
\hline & LB02 & 2,50 & - & 5,80 & $5,8 \times 10^{-4}$ & \\
\hline & Jarak $25 \mathrm{~m}$ : & & & & & Pasang \\
\hline & LB03 & 30,80 & - & 5,94 & $6,0 \times 10^{-4}$ & \\
\hline & LB04 & 35,50 & - & 6,15 & $6,2 \times 10^{-4}$ & \\
\hline & Efluen 2 : & & & & & Pukul 16.00-17.00 \\
\hline & & 45,20 & 0,005 & - & - & \\
\hline & & 51,20 & 0,005 & - & - & \\
\hline & Jarak $75 \mathrm{~m}$ : & & & & & Surut \\
\hline & LB05 & 34,22 & - & 2,52 & $1,2 \times 10^{-4}$ & \\
\hline & LB06 & 30,70 & - & 3,00 & $1,3 \times 10^{-4}$ & \\
\hline \multirow{15}{*}{$\begin{array}{c}\text { Hotel C } \\
\text { (Kelas Melati) }\end{array}$} & Efluen 1: & & & & & Pukul 12.00-13.00 \\
\hline & & 15197,40 & 0,007 & - & - & \\
\hline & & 13550,20 & 0,008 & - & - & \\
\hline & Jarak $0 \mathrm{~m}$ : & & & & & Pasang \\
\hline & $\mathrm{LC} 01$ & 4,30 & - & 80,30 & $8,4 \times 10^{-4}$ & \\
\hline & LC02 & 3,00 & - & 75,50 & $9,2 \times 10^{-4}$ & \\
\hline & Jarak 25 m : & & & & & Pasang \\
\hline & LC03 & 68,60 & - & 27,80 & $6,7 \times 10^{-4}$ & \\
\hline & LC04 & 55,72 & - & 25,55 & $7,3 \times 10^{-4}$ & \\
\hline & Efluen 2 : & & & & & Pukul 16.00-17.00 \\
\hline & & 5157,40 & 0,006 & - & - & \\
\hline & & 3250,20 & 0,008 & - & - & \\
\hline & Jarak $75 \mathrm{~m}$ : & & & & & Surut \\
\hline & LC05 & 69,20 & - & 4,35 & $1,4 \times 10^{-4}$ & \\
\hline & LC06 & 72,45 & - & 4,50 & $1,5 \times 10^{-4}$ & \\
\hline \multirow[t]{6}{*}{ Tanah Merah } & Pasang : & & & & & Pasang \\
\hline & TM01 & 0,00 & - & 3,38 & $4,9 \times 10^{-4}$ & \\
\hline & TM02 & 0,00 & - & 2,59 & $4,5 \times 10^{-4}$ & \\
\hline & Surut : & & & & & Surut \\
\hline & TM03 & 0,00 & - & 4,83 & $2,1 \times 10^{-4}$ & \\
\hline & TM04 & 0,00 & - & 4,95 & $1,8 \times 10^{-4}$ & \\
\hline \multirow{6}{*}{ Alak } & Pasang : & & & & & Pasang \\
\hline & AL01 & 0,00 & - & 2,75 & $1,1 \times 10^{-4}$ & \\
\hline & AL02 & 0,00 & - & 2,60 & $1,3 \times 10^{-4}$ & \\
\hline & Surut: & & & & & Surut \\
\hline & AL03 & 0,00 & - & 4,50 & $1,0 \times 10^{-4}$ & \\
\hline & AL04 & 0,00 & - & 4,35 & $1,1 \times 10^{-4}$ & \\
\hline
\end{tabular}

Sumber : Hasil analisis.

Keterangan :

Effluen 1

Effluen 2

Air laut jarak 0 meter dari hotel

Air laut jarak 25 meter dari hotel

Air laut jarak 75 meter dari hotel

Pengambilan sampel efluen limbah cair hotel pada pukul 12.00-13.00 WITA Pengambilan sampel efluen limbah cair hotel pada pukul 16.00-17.00 WITA Pengambilan sampel air laut pada pukul 12.00-13.00 WITA (air pasang) Pengambilan sampel air laut pada pukul 12.00-13.00 WITA (air pasang) Pengambilan sampel air laut pada pukul 16.00-17.00 WITA (air surut) 